\title{
Transplant Surgery Fellow Perceptions About Training and the Ensuing Job Market-Are the Right Number of Surgeons Being Trained?
}

\author{
D. J. Reicha,*, J. C. Magee ${ }^{b}, K^{\text {K. Gifford }}{ }^{c}$, \\ R. M. Merion ${ }^{b}$, J. P. Roberts ${ }^{d}$, \\ G. B. G. Klintmalm ${ }^{\mathrm{e}}$, P. G. Stock ${ }^{\mathrm{d}}$ and the ASTS \\ Fellowship Training Committee \\ a Drexel University College of Medicine, Philadelphia, PA \\ b University of Michigan Medical School, Ann Arbor, MI \\ ${ }^{c}$ American Society of Transplant Surgeons, Arlington, VA \\ ' UCSF School of Medicine, San Francisco, CA \\ e Baylor University Medical Center, Dallas, TX \\ * Corresponding author: David J. Reich, \\ david.reich@drexelmed.edu \\ Funding: none.
}

The American Society of Transplant Surgeons (ASTS) sought whether the right number of abdominal organ transplant surgeons are being trained in the United States. Data regarding fellowship training and the ensuing job market were obtained by surveying program directors and fellowship graduates from 2003 to 2005. Sixty-four ASTS-approved programs were surveyed, representing 139 fellowship positions in kidney, pancreas and/or liver transplantation. One-quarter of programs did not fill their positions. Forty-five fellows graduated annually. Most were male (86\%), aged $31-35$ years $(57 \%)$, married $(75 \%)$ and parents $(62 \%)$. Upon graduation, $12 \%$ did not find transplant jobs (including $8 \%$ of Americans/Canadians), 14\% did not get jobs for transplanting their preferred organ(s), $11 \%$ wished they focused more on transplantation and $27 \%$ changed jobs early. Half fellows were international medical graduates; $45 \%$ found US/Canadian transplant jobs, particularly $73 \%$ with US/Canadian residency training. Fellows reported adequate exposure to training volume, candidate selection, pre/postoperative care and organ procurement, but not to donor management/selection, outpatient care and core didactics. One-sixth noted insufficient 'mentoring/preparation for a transplantation career'. Currently, there seem to be enough trainees to fill entry-level positions. Onethird program directors believe that there are too many trainees, given the current and foreseeable job market. ASTS is assessing the total workforce of transplant surgeons and evolving manpower needs.

Key words: Access to transplantation, attitudes, citizenship, economics, education, quality assessment

\begin{abstract}
Abbreviations: ABS, American Board of Surgery ASTS, American Society of Transplant Surgeons; IMG, international medical school graduate; NRMP, National Resident Matching Program; RRC, Residency Review Committee.

Received 14 January 2010, revised 19 August 2010 and accepted for publication 21 August 2010
\end{abstract}

\section{Introduction}

Today, with transplantation a mature discipline, the question of whether North American programs are training an appropriate number of transplant surgeons for the workforce is not easily answered. Some in the medical community foresee an increasing demand for transplant surgeons, to meet the need generated by donor pool expansion (i.e. from use of extended criteria donors, donation after cardiac death donors and living donors), regulatory requirements that mandate rising staffing levels and attrition of older transplant surgeons who are beginning to retire. Others maintain that graduating fellows increasingly have trouble finding choice jobs, too many fellowship-training positions have been created, an overall excess of transplant surgeons will result and the annual volume of transplants per surgeon will be inadequate for individuals to maintain proficiency.

In 1998, the American Society of Transplant Surgeons (ASTS) conducted a study to determine how its program approval standards (issued in 1995) were affecting the educational quality of its fellowship programs, the number of fellows entering training and the success of fellows in securing a transplant surgery position after training (1). The study showed that approximately 45 fellows were graduating from approved programs each year and that the number of North American graduates who could not find positions in transplant surgery was increasing.

The complete ASTS approval standards for fellowship training programs in liver, kidney and pancreas transplant surgery are publicly available (2). Briefly, an ASTS-approved transplant fellowship program must have a formal structure of didactic and clinical training and provide specific volumes of transplant procedures (60 kidney transplants annually for a kidney fellowship, 50 liver transplants annually for a 


\section{Reich et al.}

liver fellowship and 20 pancreas transplants annually for a pancreas fellowship). The duration of the fellowship period must be at least 24 months, with at least 18 months spent in clinical training, to include not only operative surgery but also pre- and postoperative management of transplant patients. Before graduation, fellows must demonstrate proficiency by participating as principal surgeon in a minimum number of transplants (30 kidney transplants in a kidney fellowship, 45 liver transplants in a liver fellowship and 15 pancreas transplants in a pancreas fellowship).

In 2006, the ASTS assessed the job market for new graduates of ASTS-approved abdominal organ transplant surgery fellowship programs by surveying program directors as well as fellows who graduated in 2003, 2004 or 2005. In addition, the ASTS analyzed trainees' demographics and their perceptions of training. The results of these surveys are presented here.

\section{Methods}

Data for this study were obtained from surveying program directors and graduates of ASTS-approved abdominal organ transplant surgery fellowships. In June 2006, the ASTS Fellowship Training Committee distributed a five-question survey by email and/or facsimile to the directors of all 64 ASTS-accredited abdominal organ transplant fellowship programs then in existence in the United States and Canada. Nonresponders were reminded by phone or in person to participate through 2007.

Starting in April 2007, the ASTS Fellowship Training Committee attempted to contact all surgeons who had graduated from ASTS-approved abdominal organ transplantation fellowships in the United States and Canada in 2003, 2004 or 2005. Graduates were asked to complete a 46-question online survey (www.surveymonkey.com), with the primary purpose of gathering information about their employment. Secondary goals were to collect de- mographic information and perceptions about their fellowship training. The survey was developed by the ASTS Fellowship Training Committee.

Contact information was obtained from ASTS records and from queries to fellowship directors. The survey request was sent to graduates by email and included a description of the project, a hyperlink to the electronic survey and an assurance that responses would remain anonymous. Responders were tracked by the SurveyMonkey tool; repeat email messages to encourage nonresponders to participate were sent in May and June 2007.

Data from the fellowship director and fellowship graduate surveys were tabulated and analysis was mainly descriptive.

\section{Results}

Of the 64 fellowship program directors, 55 (86\%) responded. Survey questions and responses are shown in Table 1. Of note, one-quarter of programs did not fill all their training slots and one-third believed that too many fellows are being trained, whereas only $8 \%$ felt that too few were being trained. Program directors reported that $96 \%$ of fellows who were US or Canadian medical school graduates found jobs in transplantation. In contrast, $41 \%$ of international medical school graduates (IMGs) found transplant jobs in the United States or Canada and 65\% found jobs abroad.

Of 139 surgeons who completed ASTS-approved fellowships during the study period, contact information was obtained for $112(81 \%)$. Sixty-five surgeons completed the survey, comprising $60 \%$ of those with contact information and $47 \%$ of the total number completing fellowship. Eighteen respondents finished training in 2003, 22 in 2004 and 25 in 2005 . The response rate for each year was similar, ranging between $44 \%$ and $51 \%$ of the total number completing fellowship each particular year. Additionally,

Table 1: Program director survey

What is the standard length of training that your fellowship offers?

Has your fellowship filled each training slot in the past 3 years (2003, 2004 and 2005)? ${ }^{1}$

When it comes to the number of fellows in all US and Canadian programs, do you think we are training ${ }^{3}$

Are US/Canadian medical school graduates who are completing your program locating transplant positions? ${ }^{4}$

Are IMGs who are completing your program locating transplant positions? ${ }^{5}$

Less than 2
years $(n)^{2}$
$5 \%(3)$
Yes (n)
$73 \%(40)$
Too few (n)
$8 \%(4)$
Yes (n)
$96 \%(51)$
Yes, abroad (n)
$65 \%(22)^{6}$

$\begin{array}{cc}2 \text { years }(n) & \text { More than } 2 \\ 93 \%(51) & \text { years }(n) \\ & 2 \%(1) \\ \text { No }(n) & \\ 27 \%(15) & \\ \text { Enough (n) } & \text { Too many }(n) \\ 59 \%(32) & 33 \%(18) \\ \text { No (n) } & \\ 4 \%(2) & \text { No }(n) \\ \text { Yes, in the US or } & 12 \%(4)^{6} \\ \text { Canada (n) } & \\ 41 \%(14)^{6} & \end{array}$

\footnotetext{
${ }^{1} \mathrm{~N}=55$ directors.

${ }^{2}$ ASTS no longer accredits training for less than 2 years.

${ }^{3} \mathrm{~N}=54$ directors (one additional director did not answer this question).

${ }^{4} \mathrm{~N}=53$ directors (two additional directors did not answer this question).

${ }^{5} \mathrm{~N}=34$ directors ( 19 additional directors responded that no IMGs completed their program during these 3 years; two other directors did not answer this question).

${ }^{6}$ Some directors reported that IMGs located positions both abroad and also in the United States or Canada $(n=6)$, so the numbers in this row total more than $100 \%$.

IMGs, international medical school graduates.
} 
Transplant Surgery Fellows and the Job Market

Table 2: Fellow demographics ${ }^{1}$

\begin{tabular}{|c|c|c|c|c|}
\hline How old were you when you graduated your fellowship? & $\begin{array}{c}26-30 \text { years } \\
\text { old }(n) \\
2 \%(1)\end{array}$ & $\begin{array}{c}31-35 \text { years } \\
\text { old }(n) \\
57 \%(36)\end{array}$ & $\begin{array}{c}36-40 \text { years } \\
\text { old (n) } \\
28 \%(18)\end{array}$ & $\begin{array}{c}\text { Over } 40 \text { years } \\
\text { old }(n) \\
13 \%(8)\end{array}$ \\
\hline What is your gender? & $\begin{array}{l}\text { Male (n) } \\
86 \%(54)\end{array}$ & $\begin{array}{l}\text { Female (n) } \\
14 \%(9)\end{array}$ & & \\
\hline What is your race? & $\begin{array}{c}\text { African-American (n) } \\
2 \%(1)\end{array}$ & $\begin{array}{l}\text { Asian (n) } \\
30 \%(19)\end{array}$ & $\begin{array}{c}\text { Hispanic (n) } \\
14 \%(9)\end{array}$ & $\begin{array}{l}\text { White (n) } \\
54 \%(34)\end{array}$ \\
\hline Were you married at any time during your fellowship? & $\begin{array}{l}\text { Yes (n) } \\
75 \%(47)\end{array}$ & $\begin{array}{c}\text { No (n) } \\
25 \%(16)\end{array}$ & & \\
\hline Were you a parent at any time during your fellowship? & $\begin{array}{c}\text { Yes (n) } \\
62 \%(39)\end{array}$ & $\begin{array}{c}\text { No (n) } \\
38 \%(24)\end{array}$ & & \\
\hline What was your status when you started your fellowship? & $\begin{array}{l}\text { US citizen (n) } \\
49 \%(31)\end{array}$ & $\begin{array}{c}\text { Green card }(n) \\
5 \%(3)\end{array}$ & $\begin{array}{l}\text { H1 visa }(n) \\
16 \%(10)\end{array}$ & $\begin{array}{l}\text { J1 visa }(n) \\
30 \%(19)\end{array}$ \\
\hline
\end{tabular}

${ }^{1} \mathrm{~N}=63$ fellows (2/65 fellows who responded to the survey did not answer these questions regarding their demographics).

there were no significant differences in the responses of graduates from the different years $(2003,2004$ and 2005).

Responses to questions about age, gender, race, marital status and other demographic factors are shown in Table 2. Most respondents were male $(86 \%)$. At graduation, most fellows were 31-35 years old (57\%), had been married (75\%) and had children (62\%). Approximately 54\% of graduating fellows had attended US or Canadian medical schools (44\% US, 10\% Canadian). All 65 respondents had completed residency training prior to fellowship (61 in general surgery, three in both general surgery and urology and one in urology). Seventy-one percent completed residency training in the United States or Canada $60 \%$ in the United States, $11 \%$ in Canada and $29 \%$ in abroad). Onehalf of respondents were US or Canadian citizens when they started their fellowships. Nearly $60 \%$ of respondents took the American Board of Surgery written examination during the fellowship, and of those $80 \%$ did so during their first year of fellowship. Less than one-half of respondents $(45 \%)$ took the oral surgery board examination as a fellow and most (62\%) did so after their first fellowship year.

Nearly $90 \%$ of graduated fellows obtained positions as transplant surgeons immediately after their training was completed. Transplant positions in North American centers were obtained by $92 \%$ of fellows who were American or Canadian medical school graduates $(n=36), 73 \%$ who were IMGs with American or Canadian residency training $(n=11)$ and $28 \%$ who were IMGs with training abroad $(n=18)$. More than $80 \%$ of fellows found a position involving transplantation of their 'organ(s) of choice' (Table 3). Jobs involving liver transplantation were the most sought after but the most difficult to find. Roughly one-quarter of respondents had left their first job by the time they answered the survey (2-4 years after starting that job) (Table 3). More than three-quarters reported that their current position primarily included transplant and hepatopancreaticobiliary surgery and/or vascular access procedures, as opposed to nontransplant-related surgery (Table 4). Of the $22 \%$ who spend more than one-half their time doing nontransplant-related surgery, only one-half do so by choice (Table 4). Most of the graduates are not extensively involved in basic science or translational research; approximately $20 \%$ devote more than $25 \%$ of their time to such research (Table 4).

Survey respondents' answers to questions about their fellowship experience are shown in Table 5. Nearly 80\% of respondents reported that their fellowships were exactly 2 years in duration. Fellowship training exceeded 2 years for $8 \%$. Although fellowships shorter than 2 years are no longer permitted, $11 \%$ reported having completed such a fellowship. At least $90 \%$ of graduates agreed that they had had adequate exposure as fellows to transplant volumes, candidate selection and preoperative care, multiorgan procurements and inpatient postoperative management. However, opportunities to further enhance the quality of transplant surgery fellowship training were found in the following areas that did not achieve a greater than $90 \%$ positive response. Fellows reported adequate exposure to donor evaluation and management (70\%), outpatient management of posttransplant patients $(76 \%)$ and core didactic teaching $(60 \%)$. Five in six $(84 \%)$ agreed with the statement that they were 'properly mentored and prepared for a career in transplantation'. More than $90 \%$ of respondents reported that their workload during fellowship provided adequate and/or beneficial training, but one-half perceived the workload to have been 'extremely difficult/ grueling',

\section{Discussion}

In 1998, Kaufman and Ascher (1) reported on an ASTS Education Committee review of the status of transplant surgery fellowship training in the United States and Canada. They found that between 1991 and 1997, 327 surgeons completed ASTS-accredited transplant fellowships, with roughly 45 graduating each year. In our current survey, ASTS-approved fellowship programs are still graduating nearly the same number of fellows each year. 


\section{Reich et al.}

Table 3: Fellows' first jobs

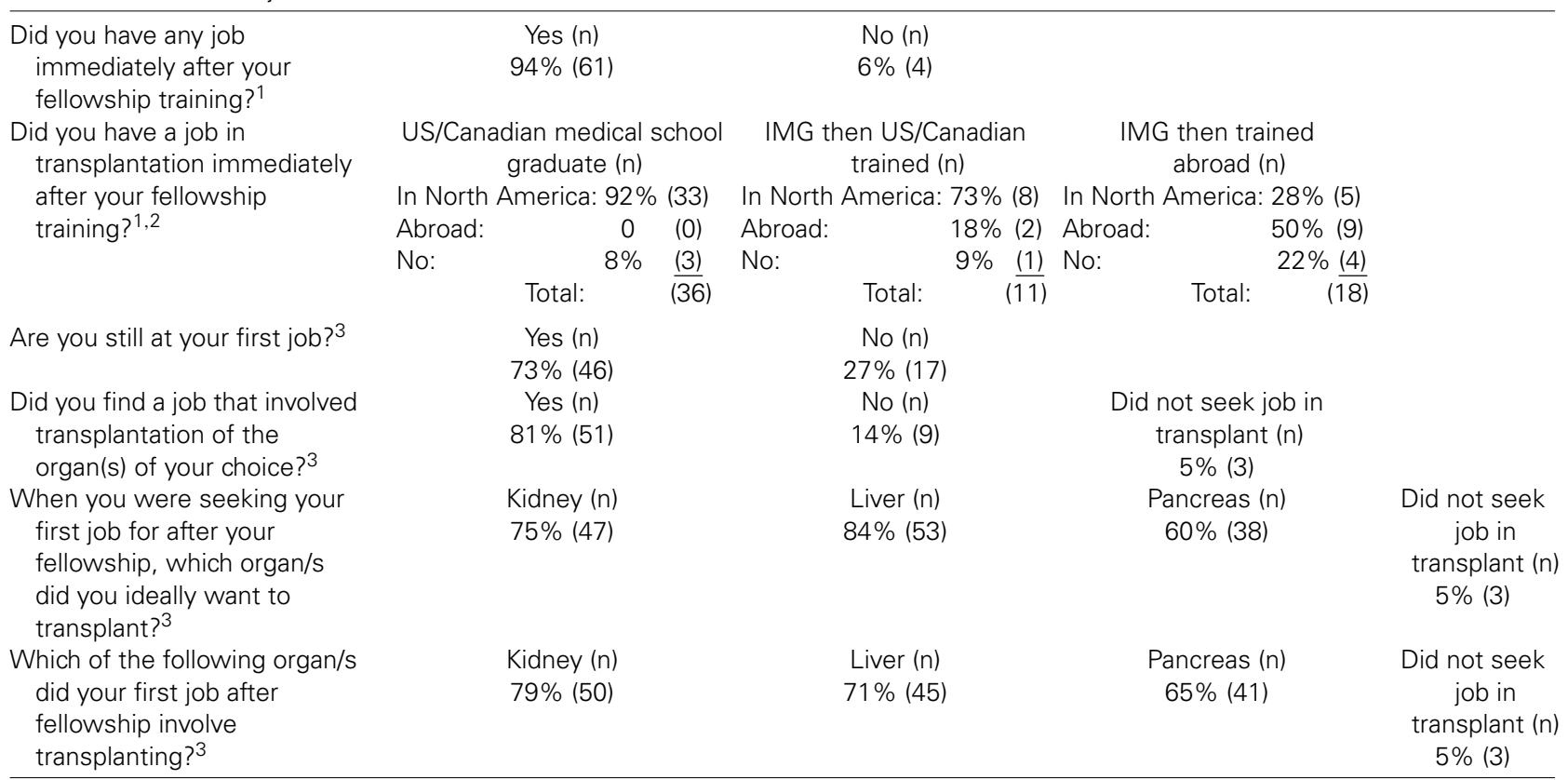

${ }^{1} \mathrm{~N}=65$ fellows.

28/65 fellows (88\%) did not obtain a job in transplantation (four did not obtain any job, one had to settle for a nontransplant job, three did not seek jobs in transplantation).

${ }^{3} \mathrm{~N}=63$ fellows (two fellows did not answer this question).

$I M G=$ international medical school graduate.

In 1998, the proportions of US or Canadian medical school graduates who trained as transplant fellows but who were not working as transplant surgeons was increasing. Of the 28 US or Canadian medical school graduates who completed transplant surgery training in 1997, six were practicing in general surgery or vascular surgery or obtaining additional transplant training.

Currently, although most trainees have transplant positions lined up before they graduate, more than $10 \%$ do not get transplant jobs (including $5-10 \%$ of US or Canadian citizens), nearly $20 \%$ do not get jobs transplanting their organ(s) of choice (most often liver) and more than $5 \%$ do not have any job by the time they graduate. More than $10 \%$ of graduates from 2003 to 2005 report wanting to do more transplant surgery now, and more than $25 \%$ left their first job within a few years, suggesting perhaps that their initial position was not ideal.

Are we training too many transplant surgeons? On the one hand, the market for transplant surgery positions appears to be relatively tight and sizable numbers of graduating fellows have trouble finding an ideal job. Scarborough et al. (3) recently used historical data from the Medicare Nationwide Inpatient Sample to project the annual number of liver transplants that will be performed in the United

Table 4: Graduates' current jobs ${ }^{1}$

\begin{tabular}{|c|c|c|c|c|}
\hline $\begin{array}{l}\text { If your current job is in clinical } \\
\text { transplantation, what organ(s) are you } \\
\text { transplanting? }\end{array}$ & $\begin{array}{l}\text { Kidney (n) } \\
77 \%(49)\end{array}$ & $\begin{array}{l}\text { Liver }(n) \\
71 \%(45)\end{array}$ & $\begin{array}{l}\text { Pancreas (n) } \\
68 \%(43)\end{array}$ & $\begin{array}{l}\text { Not doing } \\
\quad \text { transplant (n) } \\
11 \%(7)\end{array}$ \\
\hline $\begin{array}{l}\text { Which of the following best describes } \\
\text { your current clinical practice? }\end{array}$ & $\begin{array}{l}\text { Mainly transplant, HPB, } \\
\text { vascular access (n) } \\
78 \%(49)\end{array}$ & $\begin{array}{l}\text { Broader surgical } \\
\text { practice, by } \\
\text { choice (n) } \\
11 \%(7)\end{array}$ & $\begin{array}{l}\text { Broader surgical } \\
\text { practice, not by } \\
\text { choice (n) } \\
11 \%(7)\end{array}$ & $\begin{array}{l}\text { Not practicing } \\
\text { surgery }(n) \\
0\end{array}$ \\
\hline $\begin{array}{l}\text { What percent of your time is spent in } \\
\text { transplant-related surgery } \\
\text { (transplantation, HPB and/or vascular } \\
\text { access)? }\end{array}$ & $\begin{array}{l}0-24 \%(n) \\
8 \%(5)\end{array}$ & $\begin{array}{l}25-49 \%(n) \\
16 \%(10)\end{array}$ & $\begin{array}{l}50-74 \%(n) \\
16 \%(10)\end{array}$ & $\begin{array}{l}75-100 \%(n) \\
60 \%(38)\end{array}$ \\
\hline $\begin{array}{l}\text { What percent of your time is spent in } \\
\text { basic science/translational research? }\end{array}$ & $\begin{array}{l}0-24 \%(n) \\
81 \%(51)\end{array}$ & $\begin{array}{l}25-49 \%(n) \\
16 \%(10)\end{array}$ & $\begin{array}{l}50-74 \%(n) \\
3 \%(2)\end{array}$ & $\begin{array}{l}75-100 \%(n) \\
0\end{array}$ \\
\hline
\end{tabular}

${ }^{1} \mathrm{~N}=63$ fellows (2/65 fellows who responded to the survey did not answer these questions regarding their current jobs).

$\mathrm{HPB}=$ hepatopancreaticobiliary surgery. 
Transplant Surgery Fellows and the Job Market

Table 5: Fellows' perceptions about their training

\begin{tabular}{|c|c|c|c|c|c|}
\hline $\begin{array}{l}\text { How many years of clinical transplantation fellowship } \\
\text { training did you obtain? }{ }^{1}\end{array}$ & $\begin{array}{l}1 \text { year }(n) \\
8 \%(5)\end{array}$ & $\begin{array}{l}1.5 \text { years }(n) \\
3 \%(2)\end{array}$ & $\begin{array}{l}2 \text { years }(n) \\
78 \%(51)\end{array}$ & $\begin{array}{c}2.5 \text { years }(n) \\
3 \%(2)\end{array}$ & $\begin{array}{l}3 \text { years }(n) \\
8 \%(5)\end{array}$ \\
\hline $\begin{array}{l}\text { Was your program accredited to train in the following } \\
\text { organ specialties? }^{1}\end{array}$ & $\begin{array}{c}\text { Kidney (n) } \\
\text { Yes: } 89 \%(58) \\
\text { No: } 8 \%(5) \\
\text { Do not know: } \\
3 \%(2)\end{array}$ & $\begin{array}{c}\text { Liver (n) } \\
\text { Yes: } 92 \%(60) \\
\text { No: } 6 \%(4) \\
\text { Do not know: } \\
2 \%(1)\end{array}$ & $\begin{array}{c}\text { Pancreas (n) } \\
\text { Yes: } 69 \%(45) \\
\text { No: } 22 \%(14) \\
\text { Do not know: } \\
9 \%(6)\end{array}$ & & \\
\hline $\begin{array}{l}\text { How much time during fellowship was spent in basic } \\
\text { science research? }{ }^{1}\end{array}$ & $\begin{array}{l}\text { None }(n) \\
81 \%(53)\end{array}$ & $\begin{array}{l}<6 \text { months }(\mathrm{n}) \\
8 \%(5)\end{array}$ & $\begin{array}{c}6 \text { months }-1 \text { y }(n) \\
5 \%(3)\end{array}$ & $\begin{array}{l}1-1.5 \text { y }(n) \\
6 \%(4)\end{array}$ & \\
\hline $\begin{array}{l}\text { Which best describes your workload during } \\
\text { fellowship? }{ }^{2}\end{array}$ & $\begin{array}{c}\text { Not too difficult/ } \\
\text { manageable; } \\
\text { provided } \\
\text { adequate } \\
\text { training }(n) \\
43 \%(27)\end{array}$ & $\begin{array}{l}\text { Not too difficult/ } \\
\text { manageable; } \\
\text { not enough } \\
\text { training (n) } \\
2 \%(1)\end{array}$ & $\begin{array}{c}\text { Extremely } \\
\text { difficult/ } \\
\text { grueling; } \\
\text { work } \\
\text { beneficial } \\
\text { training-wise } \\
(\mathrm{n}) \\
48 \%(30)\end{array}$ & $\begin{array}{l}\text { Extremely } \\
\text { difficult/ } \\
\text { grueling; } \\
\text { much of the } \\
\text { work lacked } \\
\text { value (n) } \\
7 \%(4)\end{array}$ & \\
\hline $\begin{array}{l}\text { Did your fellowship provide adequate transplant } \\
\text { volumes to prepare you for your career? }\end{array}$ & $\begin{array}{l}\text { Yes (n) } \\
98 \%(62)\end{array}$ & $\begin{array}{l}\text { No }(n) \\
2 \%(1)\end{array}$ & & & \\
\hline $\begin{array}{l}\text { Was your exposure to candidate selection and } \\
\text { preoperative care adequate? }\end{array}$ & $\begin{array}{l}\text { Yes (n) } \\
90 \%(57)\end{array}$ & $\begin{array}{l}\text { No }(n) \\
10 \%(6)\end{array}$ & & & \\
\hline $\begin{array}{l}\text { Was your exposure to donor management and } \\
\text { selection adequate? }\end{array}$ & $\begin{array}{l}\text { Yes (n) } \\
70 \%(44)\end{array}$ & $\begin{array}{c}\text { No (n) } \\
30 \%(19)\end{array}$ & & & \\
\hline $\begin{array}{l}\text { Was your exposure to multiorgan procurements } \\
\text { adequate? }\end{array}$ & $\begin{array}{l}\text { Yes (n) } \\
98 \%(62)\end{array}$ & $\begin{array}{l}\text { No }(n) \\
2 \%(1)\end{array}$ & & & \\
\hline $\begin{array}{l}\text { Was your exposure to inpatient postoperative } \\
\text { management adequate } ?^{3}\end{array}$ & $\begin{array}{c}\text { Yes (n) } \\
100 \%(63)\end{array}$ & $\begin{array}{l}\text { No }(n) \\
0\end{array}$ & & & \\
\hline $\begin{array}{l}\text { Was your exposure to posttransplant outpatient } \\
\text { management adequate? }\end{array}$ & $\begin{array}{l}\text { Yes (n) } \\
76 \%(48)\end{array}$ & $\begin{array}{c}\text { No (n) } \\
24 \%(15)\end{array}$ & & & \\
\hline $\begin{array}{l}\text { Was the teaching (didactic coverage of core material) } \\
\text { adequate? }\end{array}$ & $\begin{array}{l}\text { Yes (n) } \\
60 \%(38)\end{array}$ & $\begin{array}{c}\text { No (n) } \\
40 \%(25)\end{array}$ & & & \\
\hline $\begin{array}{l}\text { Were you properly mentored and prepared for a } \\
\text { career in transplantation? }\end{array}$ & $\begin{array}{c}\text { Yes (n) } \\
84 \%(53)\end{array}$ & $\begin{array}{c}\text { No }(n) \\
16 \%(10)\end{array}$ & & & \\
\hline $\begin{array}{l}\text { Did you perform deceased donor multiorgan } \\
\text { procurements independently during your } \\
\text { fellowship (without an attending present in the } \\
\text { hospital)? }\end{array}$ & $\begin{array}{l}\text { Yes (n) } \\
76 \%(48)\end{array}$ & $\begin{array}{c}\text { No (n) } \\
24 \%(15)\end{array}$ & & & \\
\hline $\begin{array}{l}\text { Were you ready to perform kidney transplants } \\
\text { independently after completing your fellowship? }\end{array}$ & $\begin{array}{l}\text { Yes }(n) \\
96 \%(61)\end{array}$ & $\begin{array}{l}\text { No }(n) \\
2 \%(1)\end{array}$ & $\begin{array}{c}\text { Not accredited } \\
\text { (n) } \\
2 \%(1)\end{array}$ & & \\
\hline $\begin{array}{l}\text { Were you ready to perform liver transplants } \\
\text { independently after completing your fellowship? }\end{array}$ & $\begin{array}{l}\text { Yes (n) } \\
78 \%(49)\end{array}$ & $\begin{array}{c}\text { No (n) } \\
17 \%(11)\end{array}$ & $\begin{array}{l}\text { Not accredited } \\
5 \%(3)\end{array}$ & & \\
\hline $\begin{array}{l}\text { Were you ready to perform pancreas transplants } \\
\text { independently after completing your fellowship? }\end{array}$ & $\begin{array}{c}\text { Yes (n) } \\
76 \%(48)\end{array}$ & $\begin{array}{c}\text { No (n) } \\
16 \%(10)\end{array}$ & $\begin{array}{l}\text { Not accredited } \\
8 \%(5)\end{array}$ & & \\
\hline
\end{tabular}

${ }^{1} \mathrm{~N}=65$ fellows.

${ }^{2} \mathrm{~N}=62$ fellows (3/65 fellows did not answer this question).

${ }^{3} \mathrm{~N}=63$ fellows ( $2 / 65$ fellows did not answer these questions).

States through 2020. They also estimated the current and future number of surgeons performing liver transplant procedures. They concluded that the number of liver transplant procedures per surgeon, and the relationship between demand for liver transplantation and the supply of liver transplant surgeons, would remain relatively stable through 2020. They predicted that there would not be a shortage of transplant surgeons. In fact, they raised a concern voiced by Kaufman and Ascher (1) that there may be too many fellowship positions, and wondered whether transplant surgeons may have difficulty perform- ing enough procedures to maintain proficiency. As the authors noted, their study was limited by use of an administrative database that was not designed to estimate workforce requirements. Furthermore, their predictions assume that historic trends in supply and demand will continue.

On the other hand, several factors suggest that we may require an increased number of transplant surgeons in the future. First, although national transplant volumes have recently plateaued, they are significantly more than they were a few years ago. Liver transplants rose from 4,516 
Reich et al.

Table 6: Recent measures by ASTS to improve fellowship training in abdominal organ transplantation

\begin{tabular}{|c|c|c|}
\hline $\begin{array}{l}\text { Year } \\
\text { implemented }\end{array}$ & Measure & Rationale \\
\hline 2006 & $\begin{array}{l}\text { Required fellows to submit surgical procedure logs to } \\
\text { their program directors and to ASTS at regular intervals }\end{array}$ & Monitor progress and close gaps in training \\
\hline \multirow[t]{3}{*}{2007} & Joined NRMP & $\begin{array}{l}\text { Track fellowship slots; deter training of 'unofficial' } \\
\text { fellows }\end{array}$ \\
\hline & Instituted annual symposium for fellows & Education and informal mentoring and networking \\
\hline & $\begin{array}{l}\text { Instituted annual conference for directors of fellowship } \\
\text { training programs }\end{array}$ & $\begin{array}{l}\text { Discuss directors' concerns and further improve } \\
\text { training }\end{array}$ \\
\hline \multirow[t]{2}{*}{2008} & Issued fellow workload practice guidelines & Standardize training; mandate time off \\
\hline & Initiated 'Academic Universe' & $\begin{array}{l}\text { Robust online curriculum for self-directed learning } \\
\text { that can be monitored by program directors }\end{array}$ \\
\hline \multirow[t]{2}{*}{2009} & Initiated electronic submission of surgical procedure logs & Facilitate log submission and monitoring \\
\hline & $\begin{array}{l}\text { Worked with the } \mathrm{ABS} \text { and the } \mathrm{RRC} \text { to enhance } \\
\text { educational experience of residents on transplant } \\
\text { rotations }\end{array}$ & $\begin{array}{l}\text { Improve rotations; attract residents to pursue } \\
\text { transplant fellowships and careers }\end{array}$ \\
\hline
\end{tabular}

$\overline{\mathrm{ABS}}=$ American Board of Surgery; ASTS = American Society of Transplant Surgeons; NRMP = National Resident Matching Program; $\mathrm{RRC}=$ Residency Review Commission.

in 1998 to 6,318 in 2008; kidney transplants rose from 12,452 in 1998 to 16,517 in $2008(4,5)$. Second, Centers for Medicare and Medicaid Services conditions of participation and Organ Procurement and Transplantation Network policies are mandating higher staffing levels (5-7). Third, the authors speculate that younger physicians' demands for better quality of life could mean that more surgeons will be needed to perform a given volume of transplants. Finally, older transplant surgeons are retiring and we need to make sure we can replace them.

In 1995, the proportion of IMGs in ASTS fellowships had begun to increase (1). By 1998, IMGs accounted for 49\% of trainees (1), and according to our survey, this proportion remains largely unchanged (45\%). For many program directors and future employers, IMGs are an attractive option. They are usually high achievers who represent their country's 'cream of the crop'. Also, many international graduates plan to return to their home countries after their fellowships, in which case program directors are relieved of the obligation to help them find positions in North America. Even though $5-10 \%$ of fellows who graduated from American or Canadian medical schools do not find transplant jobs, an increasing number of IMGs (45\%) are finding postfellowship positions in the United States and Canada, including three-quarters of those who completed domestic residency programs.

American physicians may be reluctant to pursue careers in transplant surgery due to the demanding lifestyle and the tight job market. Since 2007, the ASTS Fellowship Training Committee has implemented several initiatives to attract high-caliber candidates to its transplant surgery fellowships, including efforts to improve surgery residents' transplant rotations by teaching more and giving them more opportunity to operate.
Over the past few years, the ASTS has made several changes to improve the quality of abdominal organ transplant surgery fellowship training in North America (Table 6). According to this study, most graduates were satisfied with the quality of their fellowships; however, certain aspects of training that required improvement were identified. Of concern, one in six graduates (16\%) disagreed with the statement that they were 'properly mentored and prepared for a career in transplantation' and a substantial fraction of graduates did not feel ready to independently perform liver and/or pancreas transplants upon completing fellowship (17\% and $16 \%$, respectively). Some of the strategies that have since been employed to address these weaknesses are as follows: (1) In 2006, the ASTS started to require submission of fellows' surgical procedure logs at regular intervals, making it possible to monitor progress of training and to close potential gaps; since January 2009 the logs have been submitted electronically. (2) In 2007, abdominal organ transplant surgery fellowships joined the $\mathrm{Na}$ tional Resident Matching Program (NRMP). Use by ASTS of the NRMP and of the surgical procedure logs has the benefit of deterring programs from training 'unofficial' fellows, who potentially dilute the official fellows' training experiences. 'Unofficial' fellows were typically IMGs who did not seek ASTS certificates after training but obtained operative experience, at times at the expense of the official fellows. Using the NRMP also facilitates tracking of each fellowship training slot and whether it is filledimportant information that used to be difficult to monitor accurately. (3) In 2007, the ASTS inaugurated an annual Transplant Surgical Fellows' Symposium, offering a 3-day meeting for senior fellows to have the opportunity for oneon-one interaction with faculty experts and peers during educational symposia and informal mentoring through networking events. (4) Also in 2007, the ASTS organized the first in a series of annual Transplant Surgery Fellowship 
Training Program Director Consensus Conferences to discuss fellowship training issues and opportunities for improvement. (5) In 2008, the ASTS issued fellow workload practice guidelines, including a minimum for time off. (6) That same year, the ASTS initiated the ASTS Academic Universe (http://www.asts.org/FellowshipTraining/ default.aspx), an online curriculum that addresses key clinical, immunologic, political, ethical and economic topics that fellows are expected to master, employing narrated audiovisual presentations, references and self-assessment tests. Program directors will be able to view their fellows' activity in the system.

The authors find it disappointing that only $19 \%$ of the graduates are extensively involved in basic science or translational research in their postfellowship job. We believe that primarily this reflects the overall increased clinical demands on the academic surgeon. That nearly $20 \%$ of graduates are significantly involved in research may be a higher rate than for other surgical specialties. It is important to find ways to attract aspiring academic surgeons to pursue fellowship training in transplant surgery and to nurture their interest in research during fellowship and the ensuing years.

One weakness of our study is that we were able to obtain contact information for only 112 of 139 surgeons, who completed fellowship training during our study period, and only 65 responded to the survey. This response rate is comparable to that of similar surveys in other medical disciplines (8-10). Another weakness relates to the timeliness of the results. Even though this report is about surgeons who completed fellowship in 2003, 2004 or 2005, a while ago, it is still the first such report available in over a decade since the original report by Kaufman and Ascher (1). It should be noted that the authors sought to assess fellows with at least 2 years' follow-up after training, so that their perceptions about their first jobs could be obtained and analyzed. Therefore, in 2007, we reached out to surgeons who had completed fellowships by 2005 . We obtained their responses and analyzed data until 2009. This report illustrates weaknesses in fellowship training that led to the above described efforts for improvement. Future studies will be able to assess the effectiveness of the improvement strategies. Given the disappointingly small number of US/Canadian surgeons who currently pursue training in transplant surgery, and the increasing focus on transplant workforce issues, we believe that this report is relevant to current transplant surgery fellows and academic transplant surgery faculty, as well as to residents considering pursuit of a transplant surgery fellowship and the residents' advisors.

One-third of program directors felt that we are training too many fellows but $8 \%$ believe we are training too few. Ascertainment of the appropriate number of abdominal organ transplant surgeons to train annually requires robust understanding of the complete workforce of transplant sur- geons. Although the number of transplants performed annually is known, there is no repository of complete information on the distribution of those transplants among the ranks of transplant surgeons. The ASTS has started to carefully track transplant surgery fellows through the NRMP and the surgical procedure logs, but it lacks data on more experienced surgeons and their practice patterns. The need to determine the right number of fellows to train is only one component of efforts by ASTS to better understand the dynamics of the transplant surgery workforce.

It seems unlikely that there will be a shortage of abdominal organ transplant surgeons in the near future, and the market may be in danger of becoming saturated. The ASTS Ad Hoc Committee on Workforce has embarked on a detailed assessment of the current national workforce of transplant surgeons, workforce attrition rates, evolving manpower needs and the postfellowship job market. Although most graduates of transplant surgery fellowships reported that their training was adequate, the ASTS continues to seek ways to improve the educational quality and lifestyle of fellowship training, so as to attract premier surgical residents to the specialty of transplantation, and continue to produce a cadre of highly qualified transplant surgeons for the future.

\section{Acknowledgments}

The authors thank Katrina Crist, MBA, ASTS Executive Director, for outstanding leadership, and both Diana M. Winters, Drexel University College of Medicine, and Nancy Ehrlich Lapid, for expert editorial assistance.

\section{Disclosure}

The authors of this manuscript have no conflicts of interest to disclose as described by the American Journal of Transplantation.

\section{References}

1. Kaufman DB, Ascher NL Education Committee of the ASTS. Quo vadis, my transplant fellow: A discussion of transplant surgery fellowship training activity in the United States and Canada: 19911997. Education Committee of the American Society of Transplant Surgeons. Transplantation 1998; 65: 269-272.

2. ASTS Accreditation of Abdominal Transplant Surgery Fellowship Programs. Accessible at http://www.asts.org/fellowshiptraining/ accreditation.aspx. Accessed 5/11/2009.

3. Scarborough JE, Tuttle-Newhall JE, Pietrobon R et al. Supply and demand for liver transplant surgery: Are we training enough surgeons? HPB (Oxford) 2008; 10: 25-29.

4. Department of Health and Human Services. Organ Procurement and Transplantation Network Data. Accessible at http://optn. transplant.hrsa.gov/latestData/step2.asp. Accessed 5/11/2009.

5. Tuttle-Newhall JE, Krishnan SM, Levy MF, McBride V, Orlowski JP, Sung RS. Organ donation and utilization in the United States: 1998-2007. Am J Transplant 2009; 9: 879-893. 


\section{Reich et al.}

6. Organ Procurement and Transplantation Network Bylaws. United Network for Organ Sharing. Designated Transplant Program Criteria, ATTACHMENT I TO APPENDIX B OF THE OPTN BYLAWS. Accessible at http://www.unos.org/policiesandBylaws2/ bylaws/UNOSByLaws/pdfs/bylaw_122.pdf. Accessed 5/11/2009.

7. Centers for Medicare \& Medicaid Services (CMS), HHS. Medicare program; hospital conditions of participation: requirements for approval and re-approval of transplant centers to perform organ transplants; final rule. Fed Regist 2007; 72: 15197-15280.

8. Qualia CM, Baldwin CD, Rossi TM, Wang H, Brown MR. Pedi- atric gastroenterology fellows, class of 2007: how well are they prepared for the future? J Pediatr Gastroenterol Nutr 2008; 47: 327-333.

9. Mason AD, Biehler JL, Linares MY, Greenberg B. Perceptions of pediatric emergency medicine fellows and program directors about research education. Acad Emerg Med 1999; 6: 10611065.

10. Carmody S, Meier D, Billings JA, Weissman DE, Arnold RM. Training of palliative medicine fellows: a report from the field. J Palliat Med 2005; 8: 1005-1015. 